\title{
Isolates of viral hemorrhagic septicemia virus from North America and Europe can be detected and distinguished by DNA probes
}

\author{
W. N. Batts ${ }^{1}$, C. K. Arakawa ${ }^{1}$, J. Bernard ${ }^{2}$, J. R. Winton ${ }^{1}$ \\ ${ }^{1}$ National Fisheries Research Center, Building 204 Naval Station, Seattle, Washington 98115, USA \\ ${ }^{2}$ Institut National de la Recherche Agronomique, Domaine de Vilvert, F-78352 Jouy en Josas, Cedex, France
}

\begin{abstract}
Biotinylated DNA probes were constructed to hybridize with specific sequences within the messenger RNA (mRNA) of the nucleoprotein $(N)$ gene of viral hemorrhagic septicemia virus (VHSV) reference strains from Europe (07-71) and North America (Makah). Probes were synthesized that were complementary to: (1) a 29 -nucleotide sequence near the center of the $\mathrm{N}$ gene common to both the 07-71 and Makah reference strains of the virus; (2) a unique 28nucleoticle sequence that followed the open reading frame of the Makah N gene mRNA, most of which was absent in the 07-71 strain; and (3) a 22-nucleotide sequence within the 07-71 N gene that had 6 mismatches with the Makah strain. Sixteen diverse isolates of VHSV from North America and Europe were tested by dot blot hybridization. The first probe reacted with all isolates of the virus, the second probe reacted with only the North American isolates (including those from Pacific cod), and the third probe reacted with only the European isolates, including those from rainbow trout, brown trout and Atlantic cod. The probes did not react with mRNA extracted from uninfected cells or from cells infected with infectious hematopoietic necrosis virus (IHNV), a related fish rhabdovirus. The results showed that VHSV isolates from North America and Europe formed 2 genetically distinct strains of the virus in which isolates from different years or species of fish on each continent were more related to each other than to isolates from the other continent. The results of this and other studies indicate that the North American strain of VHSV is enzootic in the North Pacific Ocean and is not a result of a recent importation of fish from Europe. When used in conjunction with a biotinylated probe that recognizes all isolates of IHNV, these reagents promise to simplify the detection of salmonid rhabdoviruses.
\end{abstract}

KEY WORDS: DNA probe - Rhabdovirus - VHSV

Viral hemorrhagic septicemia (VHS) is the most important viral disease of trout in Europe (Wolf 1988). Caused by a rhabdovirus (VHSV), the disease is responsible for killing millions of rainbow trout
Oncorhynchus mykiss each year at hatcheries throughout much of Europe. Regulations in the United States and Canada have been enacted to prevent the introduction of VHSV into North America. In 1988, routine examinations of adult chinook $O$. tshawytscha and coho $O$. kisutch salmon returning to hatcheries in western Washington State, USA, produced the first isolates of VHSV from North America (Brunson et al. 1989, Hopper 1989). Serological analyses using polyclonal and monoclonal antisera were not able to distinguish the novel isolates from the typical European reference strains (F1 or 07-71) of the virus (Winton et al. 1991). Initially, VHSV was feared to have been imported from Europe, perhaps by commercial aquaculture interests, which had been increasing the numbers of Atlantic salmon Salmo salar cultured in net pens in the Puget Sound area of western Washington. Existing fish health policies of the State of Washington and the U.S. Fish and Wildlife Service mandated the destruction of all fish at the hatcheries, and significant efforts were made to eradicate the virus from North America by complete disinfection of the 2 facilities. However, VHSV was subsequently isolated from additional stocks of salmon in Washington (Eaton et al. 1990, Stewart et al. 1990) and from Pacific cod Gadus macrocephalus caught in the wild in Prince William Sound, Alaska, USA (Meyers et al. 1992). The recovery of VHSV from stocks of adult salmon returning directly from the open ocean and from a marine fish species gave rise to the belief that the virus had been enzootic in the North Pacific Ocean for some time. In vivo investigations showed that isolates of the North American strain were significantly less virulent for 
trout and salmon compared with isolates from Europe (Winton et al. 1991). This led to management decisions that recovery of a 'North American-type' isolate of VHSV from adult salmon returning from the Pacific Ocean would no longer require the destruction of stocks, but that isolation of a 'European-type' strain should still be met with a strong response.

Initially, there was no method to distinguish the virulent 'European-type' isolates of VHSV from those of the North American strain, but further genetic analysis showed that members of the North American and European strains formed 2 distinct fingerprint groups following 2-dimensional electrophoresis of T1 ribonuclease digests of the viral genomes (Oshima et al. 1993). When the nucleotide sequence of the nucleoprotein $(\mathrm{N})$ gene of the Makah strain of VHSV was determined (Bernard et al. 1992) and compared with the $\mathrm{N}$ gene sequence for the 07-71 strain of VHSV from France (Bernard et al. 1990), the sequences diverged by ca $13 \%$, sufficient to indicate that the strains had evolved separately for a significant period and that the North American isolates were not a recent import (Bernard et al. 1991).

In this study, we evaluated a series of nonradioactive DNA probes for their ability to recognize either common or unique sequences of VHSV in order to provide fish health specialists with a rapid method for distinguishing the North American and European strains of the virus.

Materials and methods. Probe selection and synthesis: Four oligonucleotide probes were synthesized on a PCR-mate DNA synthesizer (Applied Biosystems, Inc., Foster City, CA, USA) with 3 biotin (B) phosphoramidites (BioTEG, Glen Research Corp., Sterling, VA, USA) attached to the 5 ' end. Sites for 3 of the probes were selected following computer alignment of the $N$ gene sequences of European (07-71) and North American (Makah) reference strains of VHSV (Bernard et al. 1990, Bernard et al. 1991, 1992). The first probe was 29 nucleotides long (5'-BBBTTCTTGGTGATGTACTTGATCATCTTGTC-3') and was synthesized to be complementary (antisense) to the mRNA sequence from nucleotides 430 to 458 of the open reading frame (ORF) that was identical in the $N$ genes of both isolates. The second probe (5'-BBBAGAGGCTTGTTGTGTGGAACAGCCAGTG-3') was synthesized to be complementary to a unique 28-base sequence that occurred immediately downstream of the stop codon at the end of the nucleocapsid coding region of the Makah isolate and that was absent in the 07-71 isolate. The third probe (5'-BBB-TTCTGCAACAAGCTCAGCGAAC-3') was made to be complementary to a 22-base sequence from nucleotides 990 to 1011 of the ORF of the $\mathrm{N}$ gene of the $07-71$ isolate where 6 mismatches with the Makah isolate were present. The fourth probe was complementary to a sequence described by Deering et al. (1991) within the $N$ gene mRNA of IHNV (Gilmore \& Leong 1988) and was included as a control.

Cells and viruses: Chinook salmon embryo (CHSE214) cells (Lannan et al. 1984) were maintained in Eagle's minimum essential medium supplemented with $10 \%$ fetal bovine serum, $0.3 \%$ tryptose phosphate broth, $2 \mathrm{mM}$ L-glutamine, and sodium bicarbonate at $20^{\circ} \mathrm{C}$. Eight isolates of VHSV from Europe were selected to represent the maximum possible diversity and compared with all 8 isolates of VHSV recovered from fish in North America to date (Table 1). An isolate of IHNV from steelhead Oncorhynchus mykiss in Oregon and uninfected cell culture controls were included. The concentration of each virus isolate was determined by plaque assay (Batts \& Winton 1989) and aliquots stored at $-70^{\circ} \mathrm{C}$. Duplicate preformed monolayers of CHSE-214 cells in $150 \mathrm{~cm}^{2}$ flasks $(1.5 \times$ $10^{7}$ cells per flask) were infected by the addition of virus isolates at a multiplicity of infection (MOI) of 10 plaque-forming units ( $P F U$ ) cell ${ }^{-1}$, except for the Atlantic cod Gadus morhua ulcus syndrome isolate (MOI of 1), which does not replicate to concentrations sufficient to produce high-titer stocks (Jensen et al. 1979). Two control culture flasks contained only cell monolayers with culture medium. All flasks were placed on a rocker platform for $2 \mathrm{~h}$ at room temperature, Actinomycin D was added to the medium in the flasks $\left(0.1 \mu \mathrm{g} \mathrm{ml} \mathrm{m}^{-1}\right)$ to inhibit cellular transcription, and the cultures were incubated at $15^{\circ} \mathrm{C}$ for ca $23 \mathrm{~h}$.

RNA extraction and purification: Infected and control cells were rinsed with phosphate buffered saline, scraped from each duplicate flask, and pooled into $50 \mathrm{ml}$ centrifuge tubes. Messenger RNA was extracted from infected and control cell cultures by the use of Fast Track kits (Invitrogen, San Diego, CA, USA) according to the manufacturer's instructions. Following the elution of mRNA from oligo (dT) cellulose spin columns, the RNA was precipitated with sodium acetate and ethanol at $-70^{\circ} \mathrm{C}$. Tubes were subjected to centrifugation at $15800 \times g$ for $15 \mathrm{~min}$, the ethanol removed, and the pellets dried in a Speed Vac centrifuge. Pellets were resuspended in $100 \mu \mathrm{l}$ distilleddeionized water and incubated at $65^{\circ} \mathrm{C}$ for $15 \mathrm{~min}$.

RNA dot blot: The dot blot procedure of Deering et al. (1991) was modified as follows. Purified mRNA ( $30 \mu \mathrm{l})$ was diluted in $370 \mu \mathrm{l}$ of $20 \times$ standard saline citrate (SSC; $1 \times \mathrm{SSC}=0.3 \mathrm{M} \mathrm{NaCl}, 0.03 \mathrm{M}$ citric acid) and stored on ice. A $0.45 \mu \mathrm{m}$ nitrocellulose membrane (GIBCO BRL, Gaithersburg, MD, USA) was moistened in distilled-deionized water, soaked in $10 \times \mathrm{SSC}$ for 5 min, then installed into a 96 -well dot blotting manifold (GIBCO BRL). A volume of $200 \mu \mathrm{l}$ of $10 \times \mathrm{SSC}$ was added to each well, and a vacuum was briefly applied 
Table 1. Isolates of viral hemorrhagic septicemia virus (VHSV) from North America and Europe used in this study. An isolate of infectious hematopoietic necrosis virus (IHNV) and an uninfected cell culture were included as controls

\begin{tabular}{|c|c|c|c|c|}
\hline Virus isolate & Code & Year & Location & Species \\
\hline \multicolumn{5}{|l|}{ North American strain } \\
\hline Makah & 1 & 1988 & Washington, USA & Coho salmon Oncorhynchus kisutch \\
\hline Orcas Island & 2 & 1988 & Washington, USA & Chinook salmon O. tshawytscha \\
\hline Lummi & 3 & 1989 & Washington, USA & Coho salmon $O$. kisutch \\
\hline Soleduck & 4 & 1989 & Washington, USA & Coho salmon $O$. kisutch \\
\hline Bogachiel & 5 & 1989 & Washington, USA & Coho salmon $O$. kisutch \\
\hline Prince William Sound & 6 & 1990 & Alaska, USA & Pacific cod Gadus macrocephalus \\
\hline Prince William Sound & 7 & 1991 & Alaska, USA & Pacific cod G. macrocephalus \\
\hline Clearwater & 8 & 1991 & Washington, USA & Coho salmon $O$. kisutch \\
\hline \multicolumn{5}{|l|}{ European strain } \\
\hline 07.71 & 9 & 1971 & France & Rainbow trout Oncorhynchus mykiss \\
\hline Grasmuck & 10 & 1984 & France & Rainbow trout $O$. mykiss \\
\hline $23-75$ & 11 & 1975 & France & Brown trout Salmo trutta \\
\hline Egtved (F1) & 12 & 1962 & Denmark & Rainbow trout $O$. mykiss \\
\hline Hededam & 13 & 1970 & Denmark & Rainbow trout $O$. mykiss \\
\hline Klapmolle & 14 & 1988 & Denmark & Rainbow trout $O$. mykiss \\
\hline Rindsholm & 15 & 1988 & Denmark & Rainbow trout $O$. mykiss \\
\hline Cod ulcus syndrome & 16 & 1979 & Denmark & Atlantic cod Gadus morhua \\
\hline \multicolumn{5}{|l|}{ Controls } \\
\hline Round Butte IHNV & 17 & 1976 & Oregon, USA & Steelhead $O$ mykiss \\
\hline Uninfected cells & 18 & & & \\
\hline
\end{tabular}

to ensure that the membrane was moist when RNA was added to wells. Four wells received $80 \mu \mathrm{l}$ of each RNA solution, and then vacuum was applied. Membranes were removed from the manifold, cut into 4 pieces, and nucleic acids were attached to the membrane by using a UV Stratalinker (Stratagene, La Jolla, CA, USA). Each membrane was transferred into a separate hybridization pouch with $15 \mathrm{ml}$ of prehybridization blocking solution $[10 \times$ Denhardt's solution (5'-3', Inc., Boulder, CO, USA), $2 \times \mathrm{SSC}, 1 \%$ sodium dodecyl sulphate (SDS; Sigma Chemical Corp., St. Louis, MO, USA), and $0.1 \mathrm{mg} \mathrm{m}^{-1}$ sonicated salmon sperm DNA (5'-3', Inc.)] for $1 \mathrm{~h}$ incubation at $53^{\circ} \mathrm{C}$.

Probe hybridization to target RNA: Each probe solution was added to hybridization pouches at $1.5 \mu \mathrm{g}$ per $15 \mathrm{ml}$ of prehybridization solution and allowed to incubate at $53^{\circ} \mathrm{C}$ overnight in a shaker water bath. The probe solutions were removed from the pouches and stored at $-20^{\circ} \mathrm{C}$ for future reuse. Membranes were rinsed briefly in post-hybridization solution $(2 \times \mathrm{SSC}$, $0.1 \%$ SDSj, then washed for $15 \mathrm{~min}$ on a rocker at room temperature. A final 15 min wash was performed at $55^{\circ} \mathrm{C}$ to remove excess background.

Spot development: Membranes were rinsed briefly in buffer $\mathrm{A}(0.1 \mathrm{M}$ Tris- $\mathrm{HCl}$ at $\mathrm{pH} 7.5,0.1 \mathrm{M} \mathrm{NaCl}$, $2 \mathrm{mM} \mathrm{MgCl}_{2}, 0.05 \%$ Triton X-100; Riley et al. 1986), then incubated in buffer $\mathrm{A}(40 \mathrm{ml})$ containing $40 \mu \mathrm{l}$ streptavidin/alkaline phosphatase conjugate (GIBCO BRL) for $30 \mathrm{~min}$ on a rocker. Following a brief rinse in buffer $A$, the membranes were washed twice for $7 \mathrm{~min}$ in buffer $A$, then washed twice for 7 min in buffer $B$ (0.1 M Tris- $\mathrm{HCl}$ at $\mathrm{pH} 9.5,0.1 \mathrm{M} \mathrm{NaCl}, 50 \mathrm{mM} \mathrm{MgCl}_{2}$; Riley et al. 1986). An alkaline phosphatase detection kit (Bio-Rad Laboratories, Richmond, CA, USA) that contained nitro blue tetrazolium (NBT) and 5-bromo-4chloro-3-indolyl phosphate (BCIP) was used for production of a color reaction. Incubation was in the dark for $15 \mathrm{~min}$, before washing in distilled-deionized water.

Results and discussion. The DNA probe designed to hybridize to the sequence within the $N$ gene common to North American and European strains of VHSV reacted with $\mathrm{mRNA}$ extracted from cells infected with each of the 16 VHSV isolates tested, but not with mRNA from uninfected cells or from cells infected with IHNV, a closely related fish rhabdovirus (Fig. 1). The DNA probe complementary to the unique region near the 3' end of the mRNA of the Makah isolate of VHSV reacted only with mRNA extracted from cells infected with the 8 isolates of VHSV from North America, indicating that all the isolates shared this unique sequence, which was absent in the European strain. Similarly, the probe directed against the $\mathrm{N}$ gene sequence of the European reference strain, 07-71, hybridized only with the 8 isolates of VHSV from Europe, even though there were only 6 mismatches between the 07-71 and Makah sequences at that site. Initially, we had selected a region for development of the European-specific VHSV probe where a greater sequence divergence was present (nucleotides 311-331), but the hybridization 


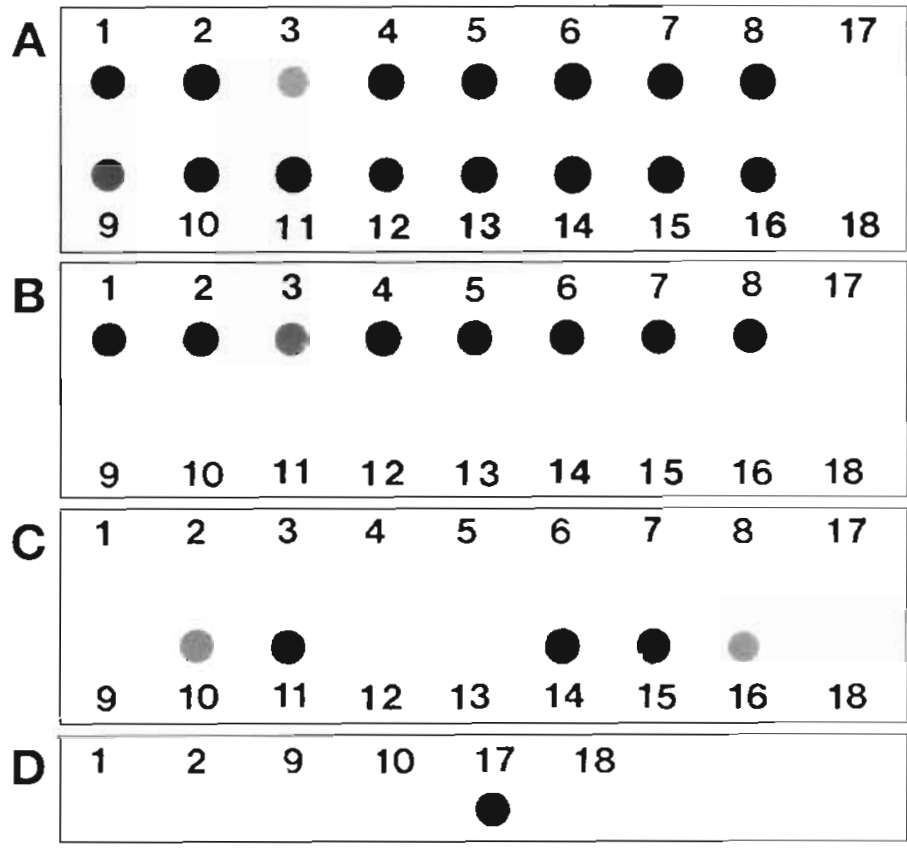

Fig. 1. Dot blot hybridization signals using DNA probes designed to recognize selected sequences within the nucleoprotein $(N)$ gene of viral hemorrhagic septicemia virus (VHSV) or infectious hematopoietic necrosis virus (IHNV). An uninfected cell culture was included as a control. Purified mRNA was extracted from infected CHSE-214 cells, applied to nitrocellulose membranes, and hybridized with biotinylated oligonucleotides designed to react with: (A) sequences common to both the North American (1 to 8) and European (9 to 16) strains of VHSV; (B) a sequence unique to the Makah isolate of VHSV from North America; (C) a sequence homologous with the 07-71 isolate from Europe; and (D) a sequence common to all strains of IHNV Codes for the isolates are given in Table 1

signals were less strong with some of the European isolates than with 07-71, perhaps because that sequence was not as well conserved. The IHNV probe, biotinylated during synthesis, seemed to be as effective as the enzyme-biotinylated probe of Deering et al. (1991) reacting only with mRNA extracted from cells infected with IHNV.

Of the 8 North American isolates of VHSV available at the time of this study, 6 isolates were obtained from Pacific salmon and 2 isolates from Pacific cod. The 8 European isolates of VHSV were carefully selected to maximize the extent of biological and serological diversity and included older and newer isolates of the virus, isolates that were representative of the 'serotypes' of VHSV, and isolates from several species of fish, including Atlantic cod. Because the probes reacted as expected with this diverse range of isolates, we think that our results can be extended to most, if not all, isolates of the virus.

Our results, based on selected sequences within the $\mathrm{N}$ gene of the virus, indicate that there is a much greater homology among isolates of VHSV from each continent, regardless of host or year of isolation, than between isolates from the different continents. Analysis of selected isolates of VHSV from North America and Europe using $\mathrm{T} 1$ ribonuclease fingerprinting (Oshima et al. 1993) indicates that these differences are present throughout the genome as well.

Upon initial isolation, the VHSV isolates from fish in North America could not be distinguished serologically from typical European reference isolates. In addition to being completely neutralized by a polyclonal antiserum made against the Danish reference strain (F1) of the virus, Western blotting analysis showed that 4 of the structural proteins of the North American isolates reacted with the antiserum (Winton et al. 1991). Immunofluorescence testing using 4 monoclonal antibodies (Lorenzen et al. 1988) directed against the individual structural proteins of VHSV also failed to differentiate between the North American and European strains (P. Vestergård Jørgensen, National Serum Laboratory, Århus, Denmark, unpubl. data). These results indicate that many of the antigenic epitopes of the virus are shared among isolates from the 2 continents despite the genetic divergence.

Our results provide some information about the epizootiology of VHSV in North America and Europe. Because the 8 isolates of VHSV from North America all seemed to originate from the marine environment, this strain of the virus is probably enzootic in the eastern Pacific Ocean, but has not yet established itself among fish in fresh water. The identification of a virus from Atlantic cod in Denmark affected with cod ulcus syndrome as an isolate of VHSV, serologically indistinguishable from the European reference strain (Jorgensen \& Olesen 1987), leads to the possibility that VHSV is also enzootic among marine species in the Baltic and North Seas. If this hypothesis is correct, VHSV may have been introduced into European trout farms from a marine source and managers of fisheries resources in the United States and Canada should be cautious about allowing the virus to adapt to fish in freshwater culture facilities, despite its apparently lower virulence.

The DNA probe techniques used in this study are specific and safe, allowing fish viruses in infected cell cultures to be identified without the use of radioactive materials. The use of these probes will provide managers with important information that will assist in making decisions about the mandated destruction of valuable stocks of fish when isolates of VHSV are recovered. Combined with a DNA probe that has been shown to recognize all isolates of IHNV, these tools will assist hatchery biologists in the rapid iden- 
tification of important viral pathogens of Pacific salmon and trout. Stocks of these probes and a detailed protocol for their use are available to fish health workers at no charge from the National Fisheries Research Center, Seattle, WA, USA.

Acknowledgements. We thank Hugh Mackie of Glen Research Corporation for the generous gift of the BioTEG biotinylated phosphoramidites in advance of their commercial availability. We also thank Pierre de Kinkelin and Paul Vestergård Jørgensen for providing the European strains of VHSV used in this study and for helpful information relating to the serology and diversity of the virus in Europe. Kathy Hopper, Ray Brunson, Bruce Stewart, Bill Eaton and Ted Meyers contributed the 8 North American strains of VHSV.

\section{LITERATURE CITED}

Batts, W. N., Winton, J. R. (1989). Enhanced detection of infectious hematopoietic necrosis virus and other fish viruses by pretreatment of cell monolayers with polyethylene glycol. J. Aquat. Anim. Hith 1: 284-290

Bernard, J., Bremont, M., Winton, J. (1991). Sequence homologies between the $\mathrm{N}$ genes of the 07-71 and Makah isolates of viral hemorrhagic septicemia virus. In: Proceedings of the Second International Symposium on Viruses of Lower Vertebrates. Oregon State University Press, Corvallis, p. $109-116$

Bernard, J., Bremont, M., Winton, J. (1992). Nucleocapsid gene sequence of a North American isolate of viral haemorrhagic septicaemia virus, a fish rhabdovirus. J. gen. Virol. 73: 1011-1014

Bernard, J., Lecocq-Xhonneux, F., Rossius, M., Thiry, M. E., de Kinkelin, P. (1990). Cloning and sequencing the messenger RNA of the $\mathrm{N}$ gene of viral haemorrhagic septicaemia virus. J. gen. Virol. 71: 1669-1674

Brunson, R., True, K., Yancey, J. (1989). VHS virus isolated at Makah National Fish Hatchery. Am. Fish. Soc. Fish Hlth Newslet. 17(2): 3-4

Deering, R. E., Arakawa, C. K., Oshima, K. H., O'Hara, P. J., Landolt, M. L., Winton, J. R. (1991). Development of a biotinylated DNA probe for detection and identification of infectious hematopoietic necrosis virus. Dis. aquat. Org 11: $57-65$

Responsible Subject Editor: F. M. Hetrick, College Park, Maryland, USA
Eaton, W. D., Hulett, J., Brunson, R., True, K. (1990). The first isolation in North America of infectious hematopoietic necrosis virus (IHNV) and viral hemorrhagic septicemia virus (VHSV) in coho salmon from the same watershed. J. Aquat. Anim. Hith 3: 114-117

Gilmore, R. D. Jr, Leong, J. C. (1988). The nucleocapsid gene of infectious hematopoietic necrosis virus, a fish rhabdovirus. Virology 167: 644-648

Hopper, K. (1989). The isolation of VHSV from chinook salmon at Glenwood Springs, Orcas Island, Washington Am. Fish. Soc. Fish Hlth Newslet. 17(2): 1

Jensen, N. J., Bloch, B., Larsen, J. L. (1979). The ulcussyndrome in cod (Gadus morhua). III. A preliminary virological report. Nord. Veterinaermed. 31: 436-442

Jørgensen, P. E. V., Olesen, N. J. (1987). Cod ulcus syndrome rhabdovirus is indistinguishable from the Egtved (VHS) virus. Bull. Eur. Ass. Fish Pathol. 7: 73-74

Lannan, C. N., Winton, J. R., Fryer, J. L. (1984). Fish cell lines: establishment and characterization of nine cell lines from salmonids. In Vitro 20: 671-676

Lorenzen, N., Olesen N. J., Jørgensen, P. E. V. (1988). Production and characterization of monoclonal antibodies to four Egtved virus structural proteins. Dis. aquat. Org. 4: 35-42

Meyers, T. R., Sullivan, J., Emmenegger, E., Follett, J., Short, S., Batts, W. N., Winton, J. R. (1992). Identification of viral hemorrhagic septicemia virus isolated from Pacific cod Gadus macrocephalus in Prince William Sound, Alaska, USA. Dis. aquat. Org. 12: 167-175

Oshima, K. H., Higman, K. H., Arakawa, C. K., de Kinkelin, P., Jørgensen, P. E. V., Meyers, T. R., Winton, J. R. (1993). Genetic comparison of viral hemorrhagic septicemia virus isolates from North America and Europe. Dis. aquat. Org. 17: $73-80$

Riley, L. K., Marshall, M. E., Coleman, M. S. (1986). A method for biotinylating oligonucleotide probes for use in molecular hybridizations. DNA 5: 333-337

Stewart, B. C., Olson, C., Lutz, S. (1990). VHS virus detected at Lummi Bay Sea Ponds, Bellingham, Washington. Am. Fish. Soc. Fish Hlth Newslet. 18(1): 2-3

Winton, J. R., Batts, W. N., Deering, R. E., Brunson, R., Hopper, K., Nishizawa, T., Stehr, C. (1991). Characteristics of the first North American isolates of viral hemorrhagic septicemia virus. In: Proceedings of the Second International Symposium on Viruses of Lower Vertebrates. Oregon State University Press, Corvallis, p. 43-50

Wolf, K. (1988). Fish viruses and fish viral diseases. Cornell University Press, Ithaca

Manuscript first received: February, 1993

Revised version accepted: May 19, 1993 